\title{
Hydrochemical Evaluation of Molybdenum Content of the Groundwater Aquifer System in Northern Jordan
}

\author{
Tasneem H. Hiasat ${ }^{*}$, Omar A. Rimawi' ${ }^{1}$ Issa M. Makhlouf ${ }^{2}$ \\ ${ }^{1}$ Department of Geology, Faculty of Science, The University of Jordan, Amman, Jordan \\ ${ }^{2}$ Department of Earth Sciences and Environment, The Hashemite University, Zarqa, Jordan \\ Email:t_hiasat@yahoo.com,rimawiom@ju,edu.jo,makhlouf@hu.edu.jo
}

How to cite this paper: Hiasat, T.H., Rimawi, O.A. and Makhlouf, I.M. (2020) Hydrochemical Evaluation of Molybdenum Content of the Groundwater Aquifer System in Northern Jordan. Journal of Water Resource and Protection, 12, 223-239.

https://doi.org/10.4236/jwarp.2020.123014

Received: February 9, 2020

Accepted: March 8, 2020

Published: March 11, 2020

Copyright $\odot 2020$ by author(s) and Scientific Research Publishing Inc. This work is licensed under the Creative Commons Attribution International License (CC BY 4.0).

http://creativecommons.org/licenses/by/4.0/

(c) (i) Open Access

\begin{abstract}
The groundwater quality of Wadi Al Arab aquifer, northwest Jordan, was assessed for its high molybdenum concentrations, which reach $1.62 \mathrm{mg} / \mathrm{L}$. This value of Mo-concentration was far beyond the Jordan Institution for Standards and Metrology (JISM) and World Health Organization (WHO) guidelines. Hydro-geochemical studies were carried out in order to assess the chemistry of the groundwater quality focusing on identifying the hydrogeochemical processes and mechanisms that are involved in the high Mo concentration. The water quality data of Wadi Al Arab boreholes (1986-2018) was collected, and the dataset analyzed. Interpretation of hydrochemical data showed that the anions are dominated by $\mathrm{HCO}_{3}^{-}$with abundance order of $\mathrm{HCO}_{3}^{-}>\mathrm{SO}_{4}^{2-}>\mathrm{Cl}^{-}>\mathrm{NO}_{3}^{-}$, while the main cation is $\mathrm{Ca}^{2+}$, with abundance order of $\mathrm{Ca}^{2+}>\mathrm{Mg}^{2+}>\mathrm{Na}^{+}>\mathrm{K}^{+}$; water type is $\mathrm{Ca}-\mathrm{HCO}_{3}^{-}$. The reason is the passage of groundwater through carbonate rocks. The distribution of the sampling points in the Gibbs diagram showed that the majority of samples are plotted within the field of rock weathering, which indicates that the main factor controlling dissolved hydrochemical components of the water samples is the dissolution of the rock-forming minerals. The scattered plot of the Mo with other critical heavy metals shows two different trend lines suggesting initiation of molybdenum to groundwater which is probably derived from oil shale and phosphate. The effects of $\mathrm{pH}$ and redox potential on Mo mobility in water are reviewed using the paurbaix diagram. The Mo species of the sampled wells are confined to the field of $\mathrm{MoO}_{4}^{(2-)}$ : anoxic/non-sulfidic condition (Fe reduction) which is located in the unconfined part of the aquifer, and $\operatorname{MoS}_{2}^{(\mathrm{s})}$ which is sulfidic condition (low and high) in the confined aquifer.
\end{abstract}




\section{Keywords}

Molybdenum, Hydrogeochmistry, Groundwater, Wadi Al-Arab

\section{Introduction}

Generally, the significant sources of contamination in groundwater are anthropogenic. However, groundwater contamination is not exclusively due to the direct input of contaminants. Further it's related to geogenic contamination as a result of the dissolution of rock-forming minerals enriched with trace elements in the aquifer [1] [2]. The leaching of metals from these rocks poses a threat to the groundwater resources and may persist for a long time in groundwater [3] [4]. This type of contamination is a public health issue worldwide with respect to molybdenum (Mo).

The concentration of molybdenum is generally present in small proportions in the natural water system. However, in the study area at Wadi Al Arab (WA) located in northwest Jordan; the carbonate aquifer is affected by geogenic contamination of groundwater by Mo. Whereas, the concentration of Mo reached $1.62 \mathrm{mg} / \mathrm{L}$ [5] [6] [7] that exceeded the WHO Guidelines for Drinking-Water Quality of $0.07 \mathrm{mg} / \mathrm{L}$, and also exceeded the Jordan Institution for Standards and Metrology (JISM) standards of $0.09 \mathrm{mg} / \mathrm{L}$ [8] [9].

The geogenic potential sources of Mo in the study area are the Cretaceous-Paleogene limestone sediments of the oil shale (B3) and the phosphorites deposits (B2/A7) which contained the highest level of molybdenum [10] [11]. These rocks are in direct contact with the groundwater resources. The rock-water interaction processes play an important role in the evolution of groundwater [12].

Based on the previous studies most researchers believed that the source of Mo is geogenic, and refers to naturally occurring elevated concentration of certain elements in groundwater having negative health effects. But the source of molybdenum is not deeply studied; it is from the organic matter in the oil shale deposits or phosphate deposits rather from pyrite or other oxides. Therefore, further detailed research will be conducted to describe the spatial variations in the mineralogical composition of the aquifer matrix lithology and its effect on the hydrochemical characteristics of groundwater resources. The two potential sources of Mo in the study area are the oil shale and the phosphorites deposits, which are in a direct contact with the groundwater resources. Their spatial distribution, dissolution processes and the prevailing water-rock interactions first will be evaluated.

\section{Study Area}

\subsection{Site Description}

Wadi Al Arab is located at the northwestern part of Irbid Governorate, about 81 
$\mathrm{km}$ from the capital city of Amman-Jordan (Figure 1), it is situated at the transition between the mountainous highland in the southeast, the high plateaus and hilly areas in the central part, the rift escarpment, and the Jordan Valley along the western part.

Wadi Al Arab well field was commenced in 1982 with five wells. Currently the well field is composed of 18 operational wells used for the water supply in Irbid. Initially the early drilled five wells were artesian flowing wells and the discharge was ranging between $640 \mathrm{~m}^{3} / \mathrm{h}$ and more than $1500 \mathrm{~m}^{3} / \mathrm{h}$ [13] [14]. The annual abstraction from these wells was 26 Million Cubic Meters (MCM). This high abstraction amount caused the water level to decline significantly and consequently leading all wells to become non-artesian flowing wells. Due to this; the abstraction rate from these wells reduced to approximately 16 - $18 \mathrm{MCM} /$ Year [15]. Since 1982, the measured decline in the water level is $118.64 \mathrm{~m} / 35 y e a r$. The average annual decline rate of groundwater level is estimated as $3.39 \mathrm{~m} /$ year [16].

The change in groundwater level leads to a dynamic groundwater system characterized by changing aquifer conditions, accompanied by changes in water quality [17] [18] [19]. As a result, the quality of produced water in the study area shows increased concentrations of heavy metals, in particular Molybdenum, Nickel, and Arsenic, which is in many wells proves a rising trend of contamination.
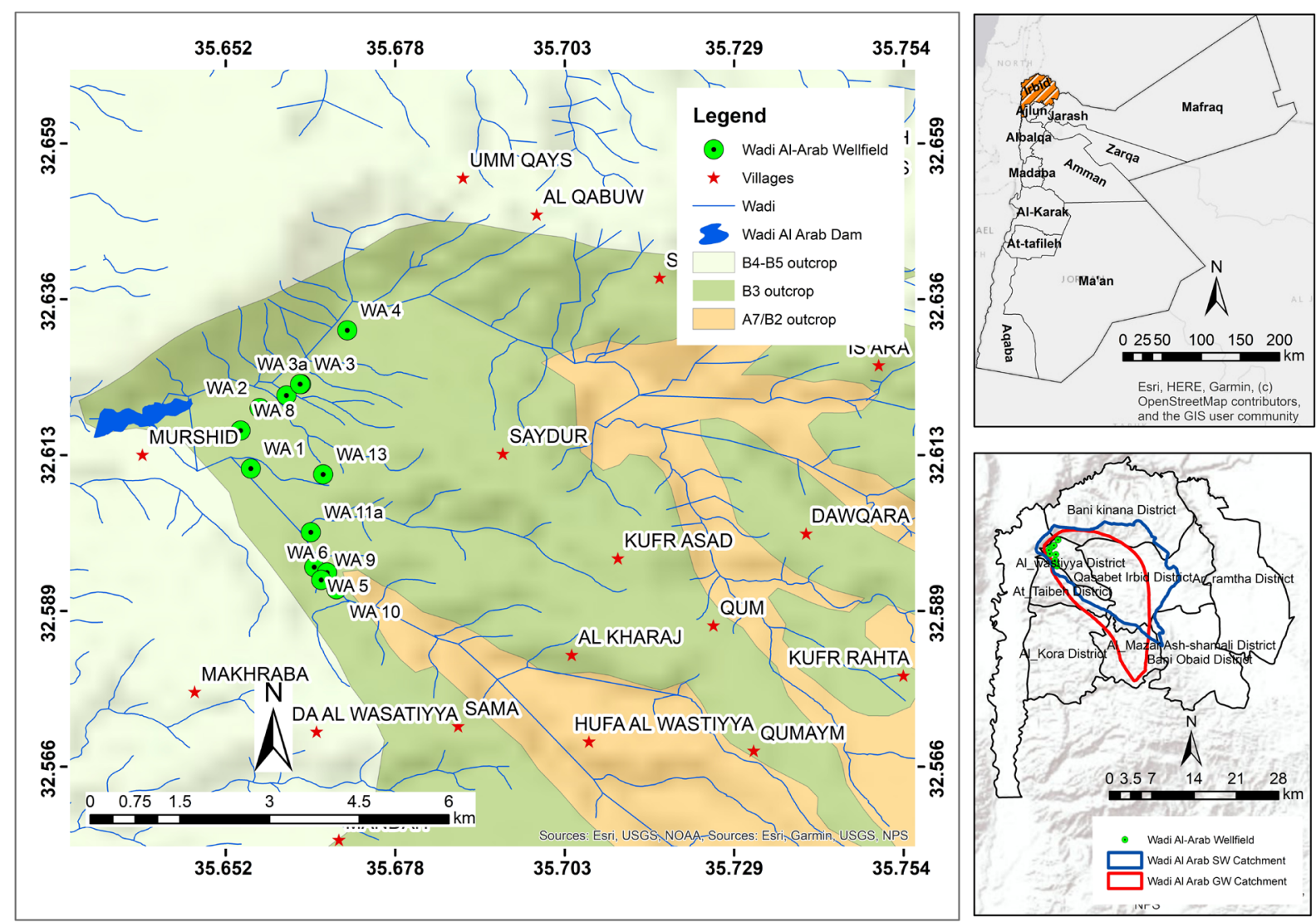

Figure 1. The hydrogeological map of Wadi Al Arab Aquifer modified after Basem (2000). 


\subsection{Geology and Hydrogeology}

The geological succession in the study area is hydrogeologicaly subdivided into lithostratigraphic units, which form systems of aquifers and aquitards. The aquifer systems in the study area include two major (Kurnub, and Amman Wadi As Sir Aquifer System), and three minor (Na'ur (A 1-2); Hummer (A4); and Rijam (A4)) [20] [21].

Amman-Wadi As Sir Aquifer (Silicified Limestone and Phosphatic Limestone) (A7/B2) is the main aquifer in the study area. The Muwaqqar Formation (B3) conformably overlies the Amman Formation (B2) in the study area. The B3 is a regional aquitard, which confines the underlying A7/B2 Aquifer system [22] [23] [24].

\section{Methodology}

Hydro-geochemical studies were carried out to identify the geochemical processes and their relation to groundwater quality of high Mo concentration. The water quality data collected from Wadi Al Arab boreholes during the period from 1986 until 2018 The collected hydrochemical dataset were tested using different hydrochemical software such as RockWare AQ-QA and Phreeqc Interactive Software in order to calculate the saturation index (SI) value for various related minerals such as calcite, aragonite, and dolomite; in order to evaluate the chemical equilibrium between minerals and water in natural environment. On the other hand, multivariate statistical analysis was conducted using SigmaPlot 14 software. Whereas; the correlation based on the Pearson's correlation coefficient, principle component analysis (PCA) and the relationship between the different variables of the analyzed hydrochemical parameters. This had been done to evaluate the factors affecting hydrochemical components of the groundwater resources in the study area.

\section{Results and Discussion}

\subsection{Major Cations and Anions}

The water quality field and analytical parameters of the major ions composition of Wadi Al Arab groundwater samples for 1986 and 2017 are shown in Table 1 and Table 2.

Most of the water samples anions are dominated by $\mathrm{HCO}_{3}^{-}$with relative abundance of $\mathrm{HCO}_{3}^{-}>\mathrm{SO}_{4}^{2-}>\mathrm{Cl}^{-}>\mathrm{NO}_{3}$, whereas; the main cation is $\mathrm{Ca}^{2+}$, with relative abundance of $\mathrm{Ca}^{2+}>\mathrm{Mg}^{2+}>\mathrm{Na}^{+}>\mathrm{K}^{+}$. The trace element content of As, Mo, and Ni exhibits increase concentration in the groundwater of Wadi Al Arab, which is beyond the concentration threshold of the Jordan Institution for Standards and Metrology (JISM), and the World Health Organization (WHO) guidelines.

\subsection{Hydro-Chemical Facies of Groundwater}

Scatter plots of the cations $\left(\mathrm{Na}^{+}, \mathrm{K}^{+}, \mathrm{Ca}^{2+}\right.$, and $\left.\mathrm{Mg}^{2+}\right)$ and anions $\left(\mathrm{HCO}_{3}^{-}, \mathrm{Cl}^{-}\right.$ 
Table 1. The major ions composition of Wadi Al Arab groundwater samples for the 1986 year.

\begin{tabular}{cccccccccccc}
\hline $\begin{array}{c}\text { Well } \\
\text { Name }\end{array}$ & $\begin{array}{c}\text { Sample } \\
\text { Year }\end{array}$ & $\begin{array}{c}\mathrm{EC} \\
(\mu \mathrm{S} / \mathrm{cm})\end{array}$ & $\begin{array}{c}\mathrm{pH}- \\
\text { value }\end{array}$ & $\begin{array}{c}\mathrm{Ca} \\
(\mathrm{mg} / \mathrm{L})\end{array}$ & $\begin{array}{c}\mathrm{Mg} \\
(\mathrm{mg} / \mathrm{L})\end{array}$ & $\begin{array}{c}\mathrm{Na} \\
(\mathrm{mg} / \mathrm{L})\end{array}$ & $\begin{array}{c}\mathrm{K} \\
(\mathrm{mg} / \mathrm{L})\end{array}$ & $\begin{array}{c}\mathrm{Cl} \\
(\mathrm{mg} / \mathrm{L})\end{array}$ & $\begin{array}{c}\mathrm{SO}_{4} \\
(\mathrm{mg} / \mathrm{L})\end{array}$ & $\begin{array}{c}\mathrm{HCO}_{3} \\
(\mathrm{mg} / \mathrm{L})\end{array}$ & $\begin{array}{c}\mathrm{NO}_{3} \\
(\mathrm{mg} / \mathrm{L})\end{array}$ \\
\hline WA 1 & 1986 & 890.00 & 7.33 & 110.09 & 36.36 & 29.13 & 4.69 & 39.05 & 63.68 & 447.33 & 1.18 \\
WA 2 & 1986 & 824.00 & 7.65 & 106.17 & 34.29 & 28.57 & 4.69 & 38.27 & 65.18 & 412.48 & 0.94 \\
WA 3 & 1986 & 785.00 & 7.77 & 105.41 & 31.19 & 24.15 & 2.54 & 37.28 & 62.64 & 392.23 & 0.60 \\
WA 4 & 1986 & 795.00 & 8.04 & 72.14 & 39.28 & 39.10 & 6.45 & 40.47 & 85.44 & 339.47 & 0.64 \\
WA 5 & 1986 & 700.00 & 7.67 & 79.09 & 29.10 & 21.47 & 5.21 & 30.41 & 22.72 & 356.04 & 10.21 \\
\hline
\end{tabular}

Table 2. The major ions composition of Wadi Al Arab (WA) groundwater samples for the 2017 year.

\begin{tabular}{|c|c|c|c|c|c|c|c|c|c|c|c|c|c|c|c|c|c|}
\hline Well & Sample & DO & EC & $\mathrm{pH}$ & TDS & Temp. & $\mathrm{Ca}$ & $\mathrm{Mg}$ & $\mathrm{Na}$ & $\mathrm{K}$ & $\mathrm{Cl}$ & $\mathrm{SO}_{4}$ & $\mathrm{HCO}_{3}$ & $\mathrm{NO}_{3}$ & As & Mo & $\mathrm{Ni}$ \\
\hline Name & Year & $\mathrm{mg} / \mathrm{L}$ & $\mu \mathrm{S} / \mathrm{cm}$ & Value & $\mathrm{mg} / \mathrm{L}$ & ${ }^{\circ} \mathrm{C}$ & $\mathrm{mg} / \mathrm{L}$ & $\mathrm{mg} / \mathrm{L}$ & $\mathrm{mg} / \mathrm{L}$ & $\mathrm{mg} / \mathrm{L}$ & $\mathrm{mg} / \mathrm{L}$ & $\mathrm{mg} / \mathrm{L}$ & $\mathrm{mg} / \mathrm{L}$ & $\mathrm{mg} / \mathrm{L}$ & $\mathrm{mg} / \mathrm{L}$ & $\mathrm{mg} / \mathrm{L}$ & $\mathrm{mg} / \mathrm{L}$ \\
\hline WA 1 & 2017 & 0.14 & 843 & 6.83 & 421.5 & 31.1 & 99.9 & 38 & 23.1 & 1.8 & 37.6 & 67.1 & 416 & 0.023 & 0.0002 & 0.04 & 0.0003 \\
\hline WA 10 & 2017 & 5.4 & 849 & 6.9 & 424.5 & 24.2 & 108 & 35.5 & 21.6 & 2.6 & 39.4 & 34.8 & 445 & 0.000 & 0.001 & 0.04 & 0.03 \\
\hline WA $11 \mathrm{a}$ & 2017 & 0.08 & 765 & 7 & 382.5 & 25.8 & 91.2 & 32.3 & 19.7 & 2.5 & 37.6 & 46.3 & 380 & 0.005 & 0.046 & 1.62 & 0.12 \\
\hline WA 12 & 2017 & 0 & 798 & 6.8 & 399 & 26.6 & 102 & 32.2 & 21.5 & 2.5 & 35.2 & 56.9 & 395 & 0.000 & 0.012 & 0.12 & 0.16 \\
\hline WA $13 a$ & 2017 & 1.5 & 753 & 6.9 & 376.5 & 26.1 & 94.4 & 30.3 & 19.9 & 2.6 & 36.2 & 48.7 & 368 & 0.000 & 0.011 & 0.62 & 0.24 \\
\hline WA 14 & 2017 & 4.2 & 793 & 7.1 & 396.5 & 27.2 & 94.7 & 31.6 & 21.7 & 2.9 & 37.5 & 55.3 & 381 & 0.000 & 0.004 & 0.25 & 0.012 \\
\hline WA 15 & 2017 & 4.13 & 788 & 7.2 & 394 & 26.4 & 98.9 & 29.9 & 20.3 & 3 & 36.8 & 59.7 & 381 & 0.022 & 0.005 & 0.33 & 0.03 \\
\hline WA 16 & 2017 & 5.4 & 765 & 7 & 382.5 & 26.4 & 97 & 30 & 19.8 & 2.3 & 35.9 & 50.8 & 369 & 0.000 & 0.006 & 0.28 & 0.03 \\
\hline WA 17 & 2017 & 2.64 & 854 & 6.93 & 427 & 29.1 & 105 & 35.8 & 24 & 2.2 & 36 & 64.4 & 430 & 0.005 & 0.001 & 0.05 & 0.01 \\
\hline WA 18 & 2017 & 2.5 & 838 & 6.91 & 419 & 26.7 & 104 & 33.4 & 23.1 & 2.7 & 35.3 & 57.4 & 430 & 0.317 & 0.004 & 0.26 & 0.15 \\
\hline WA 2 & 2017 & 1.37 & 775 & 6.76 & 387.5 & 26.8 & 96 & 30.6 & 20.5 & 2.6 & 35.5 & 52.8 & 383 & 0.088 & 0.009 & 0.34 & 0.22 \\
\hline WA 3 & 2017 & 4 & 827 & 6.8 & 413.5 & 27.2 & 104 & 33.7 & 22.8 & 2.6 & 36.4 & 61.5 & 410 & 0.000 & 0.007 & 0.21 & 0.14 \\
\hline WA 3a & 2017 & 0.2 & 826 & 6.9 & 413 & 27.2 & 104 & 34.3 & 23 & 2.6 & 35.9 & 60.4 & 409 & 0.000 & 0.008 & 0.23 & 0.13 \\
\hline WA 4 & 2017 & 3.2 & 981 & 7.1 & 490.5 & 28.2 & 111 & 38.8 & 34.6 & 3.9 & 40.3 & 114 & 430 & 0.03 & 0.008 & 0.21 & 0.06 \\
\hline WA 5 & 2017 & NA & 771 & 7.5 & 385.5 & 25.5 & 96.8 & 33.5 & 20.3 & 2.7 & 38.5 & 40.8 & 387 & 4.82 & 0.007 & 0.64 & 0.12 \\
\hline IWA 9 & 2017 & NA & 785 & 7 & 392.5 & 24.5 & 96 & 32.8 & 20.5 & 2.9 & 39 & 29.5 & 398 & 15.1 & 0.002 & 0.14 & 0.03 \\
\hline
\end{tabular}

and $\mathrm{SO}_{4}^{2-}, \mathrm{NO}_{3}^{-}$) were shown in Piper's diagram [25], classifying the hydrochemical characteristics. One main water type has been identified; all water samples were concentrated on the field of $\mathrm{Ca}-\mathrm{HCO}_{3}$, The reason is groundwater passing through carbonate rock, for cation concentration Calcium type and for anion concentration; $\mathrm{HCO}_{3}$-Type of water Predominated (Figure 2). Total hardness of the sample is classified as very hard water, which exceeds $300 \mathrm{mg} / \mathrm{L}$.

The Schöeller diagram (Figure 3) further demonstrates the uniformity and similarity of composition among the groundwater samples by the cluster of the lines of concentration from cations to anions. 


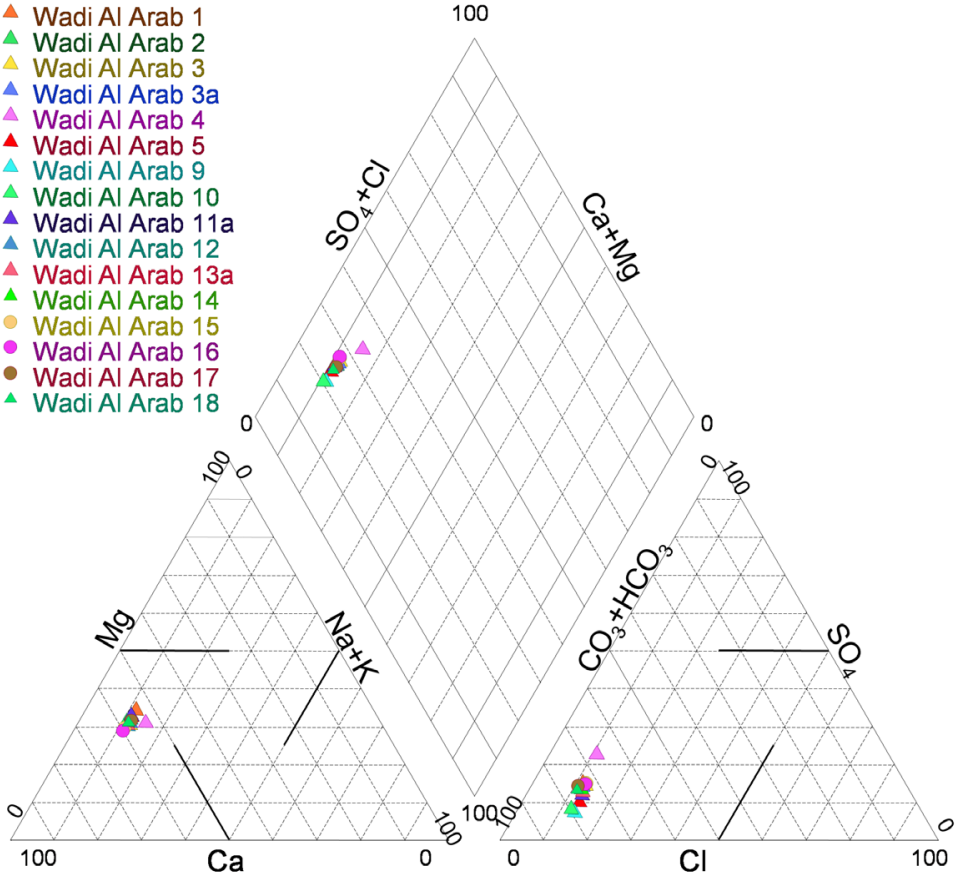

Figure 2. Piper diagram classification water type.

\section{Schoeller Diagram}

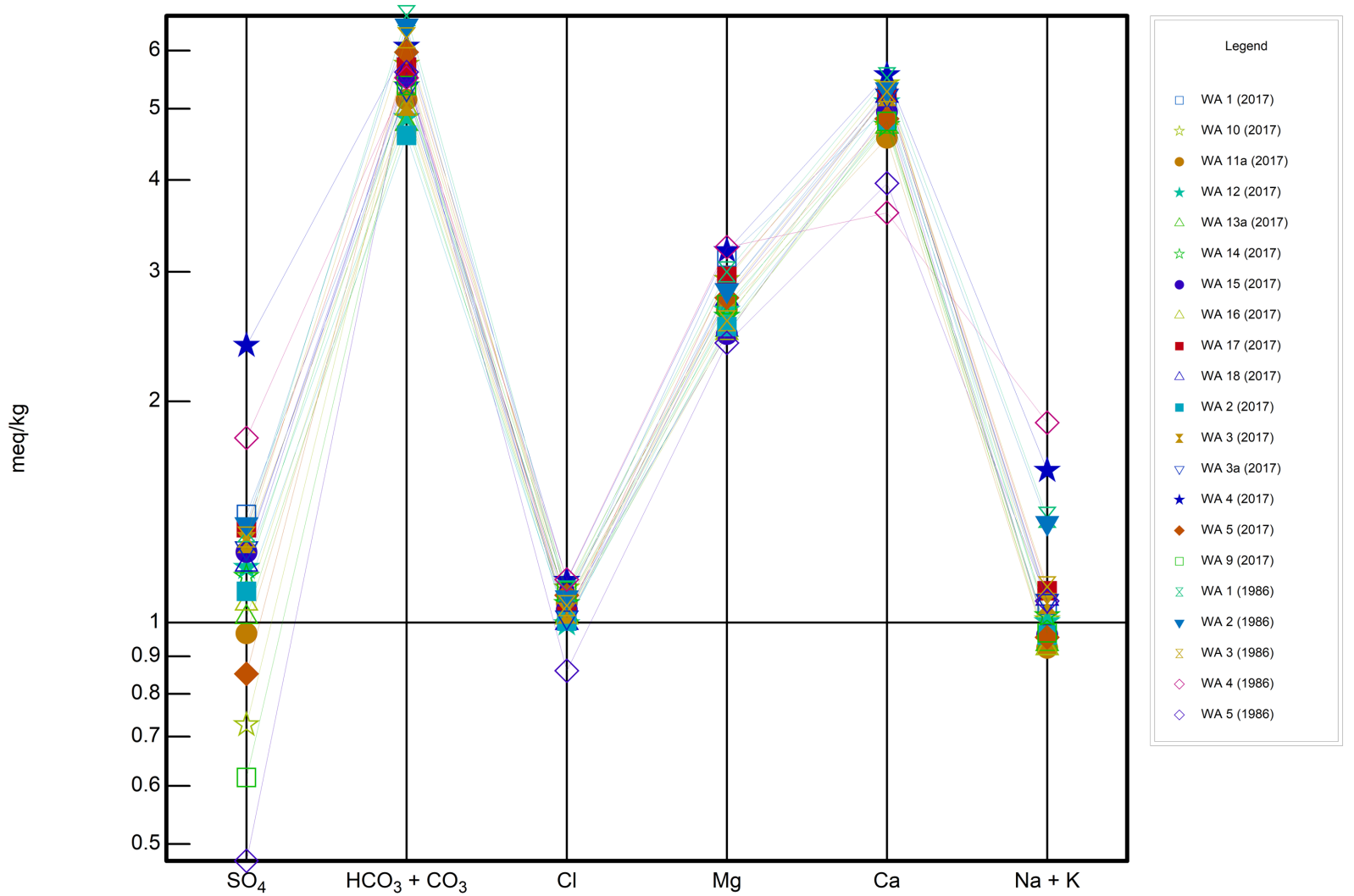

Figure 3. Schöeller diagram for different Wadi Al Arab groundwater samples for 2017 and 1986 present the variation of different ion concentrations. 


\subsection{Correlation Matrix for Analyzed Parameters of Groundwater}

The relationship between dependent and independent variables is known as Correlation Matrix, and is statistically measured. It assists in predicting the mutual relationship between two variables. The correlation between the parameters differentiates between strong (the range is +0.8 to 1.0 and -0.8 to -1.0 ), and weak (the range is +0.0 to 0.5 and -0.0 to -0.5 ). The correlation values obtained in the present study in Wadi Al Arab are presented respectively in (Table 3 and Table 4). As per the findings of the correlation matrix, it can be inferred that the correlation matrix between parameters is changed during the period between 2017 and 1986, which marks the change of the geochemical processes.

\subsection{Hydrochemical Process of Groundwater-Correlation of Major Ions}

Groundwater composition is controlled by three main hydrogeochemical processes; including water rock interaction, evaporation and precipitation. Gibbs diagram [26] is used to give an indication of the main process affecting the water quality. The distribution of the sampling points in the Gibbs diagram showed that the majority of samples are plotted within the field of rock weathering (Figure 4), which indicates that the main factor controlling dissolved hydrochemical components of the water samples is the dissolution of the rock-forming minerals.

Hydrogeochemical data for groundwater in the study area suggested the occurrence of $\mathrm{Ca}^{2+}-\mathrm{HCO}_{3}^{-}$water type as a result of the dissolution of the carbonate minerals, as shown in the following Equation (1) and Equation (2).

$$
\begin{gathered}
\mathrm{CaCO}_{3} \text { (calcite) }+\mathrm{H}_{2} \mathrm{CO}_{3} \rightarrow \mathrm{Ca}^{2+}+2 \mathrm{HCO}_{3}^{-} \\
\mathrm{Ca} \mathrm{Mg}\left(\mathrm{CO}_{3}\right)_{2} \text { (dolomite) }+2 \mathrm{H}_{2} \mathrm{CO}_{3} \rightarrow \mathrm{Ca}^{2+}+\mathrm{Mg}^{2+}+4 \mathrm{HCO}_{3}^{-}
\end{gathered}
$$

\begin{tabular}{|c|c|c|c|c|c|c|c|c|c|c|}
\hline $\begin{array}{c}\text { Pearson Product } \\
\text { Moment } \\
\text { Correlation }\end{array}$ & $\mathrm{EC}(\mu \mathrm{S} / \mathrm{cm})$ & pH-value & $\begin{array}{c}\mathrm{Ca} \\
\mathrm{mg} / \mathrm{L}\end{array}$ & $\begin{array}{c}\mathrm{Mg} \\
\mathrm{mg} / \mathrm{L}\end{array}$ & $\begin{array}{c}\mathrm{Na} \\
\mathrm{mg} / \mathrm{L}\end{array}$ & $\underset{\mathrm{mg} / \mathrm{L}}{\mathrm{K}}$ & $\underset{\mathrm{mg} / \mathrm{L}}{\mathrm{Cl}}$ & $\begin{array}{c}\mathrm{SO}_{4} \\
\mathrm{mg} / \mathrm{L}\end{array}$ & $\begin{array}{c}\mathrm{HCO}_{3} \\
\mathrm{mg} / \mathrm{L}\end{array}$ & $\begin{array}{l}\mathrm{NO}_{3} \\
\mathrm{mg} / \mathrm{L}\end{array}$ \\
\hline $\mathrm{EC}(\mu \mathrm{S} / \mathrm{cm})$ & 1.0 & -0.5 & 0.7 & 0.7 & 0.4 & -0.1 & 0.8 & 0.6 & 0.8 & -0.8 \\
\hline pH-value & & 1.0 & -0.7 & 0.2 & 0.5 & 0.3 & 0.1 & 0.4 & -0.9 & -0.1 \\
\hline Ca mg/L & & & 1.0 & -0.1 & -0.4 & -0.7 & 0.3 & 0.1 & 0.9 & -0.5 \\
\hline $\mathrm{Mg} \mathrm{mg/L}$ & & & & 1.0 & 1.0 & 0.6 & 0.9 & 0.9 & 0.1 & -0.7 \\
\hline $\mathrm{Na} \mathrm{mg/L}$ & & & & & 1.0 & 0.6 & 0.8 & 0.9 & -0.2 & -0.6 \\
\hline $\mathrm{K} \mathrm{mg/L}$ & & & & & & 1.0 & 0.1 & 0.2 & -0.5 & 0.2 \\
\hline $\mathrm{Cl} \mathrm{mg/L}$ & & & & & & & 1.0 & 1.0 & 0.3 & -1.0 \\
\hline $\mathrm{SO}_{4} \mathrm{mg} / \mathrm{L}$ & & & & & & & & 1.0 & 0.1 & -0.9 \\
\hline $\mathrm{HCO}_{3} \mathrm{mg} / \mathrm{L}$ & & & & & & & & & 1.0 & -0.4 \\
\hline $\mathrm{NO}_{3} \mathrm{mg} / \mathrm{L}$ & & & & & & & & & & 1.0 \\
\hline
\end{tabular}

Table 3. Pearson correlation matrix for Wadi Al Arab Groundwater Samples in 1986. 
T. H. Hiasat et al.

Table 4. Pearson correlation matrix for Wadi Al Arab Groundwater Samples in 2017.

\begin{tabular}{|c|c|c|c|c|c|c|c|c|c|c|c|c|c|c|c|c|c|c|}
\hline $\begin{array}{c}\text { Pearson } \\
\text { Corr. }\end{array}$ & $\begin{array}{c}\text { EC } \\
(\mu \mathrm{S} / \mathrm{cm})\end{array}$ & $\begin{array}{l}\mathrm{pH}- \\
\text { value }\end{array}$ & $\begin{array}{c}\mathrm{DO} \\
\mathrm{mg} / \mathrm{L}\end{array}$ & $\begin{array}{c}\text { Redox } \\
\mathrm{mV}\end{array}$ & $\begin{array}{l}\text { Temp } \\
{ }^{\circ} \mathrm{C}\end{array}$ & $\begin{array}{c}\mathrm{Ca} \\
\mathrm{mg} / \mathrm{L}\end{array}$ & $\begin{array}{c}\mathrm{Mg} \\
\mathrm{mg} / \mathrm{L}\end{array}$ & $\begin{array}{c}\mathrm{Na} \\
\mathrm{mg} / \mathrm{L}\end{array}$ & $\begin{array}{c}\mathrm{K} \\
\mathrm{mg} / \mathrm{L}\end{array}$ & $\begin{array}{c}\mathrm{Cl} \\
\mathrm{mg} / \mathrm{L}\end{array}$ & $\begin{array}{c}\mathrm{SO}_{4} \\
\mathrm{mg} / \mathrm{L}\end{array}$ & $\begin{array}{c}\mathrm{HCO}_{3} \\
\mathrm{mg} / \mathrm{L}\end{array}$ & $\begin{array}{l}\mathrm{NO}_{3} \\
\mathrm{mg} / \mathrm{L}\end{array}$ & $\begin{array}{c}\mathrm{Fe} \\
\mathrm{mg} / \mathrm{L}\end{array}$ & $\begin{array}{c}\mathrm{As} \\
\mathrm{mg} / \mathrm{L}\end{array}$ & $\begin{array}{c}\mathrm{Mo} \\
\mathrm{mg} / \mathrm{L}\end{array}$ & $\begin{array}{c}\mathrm{Ni} \\
\mathrm{mg} / \mathrm{L}\end{array}$ & $\begin{array}{c}\mathrm{U} \\
\mathrm{mg} / \mathrm{L}\end{array}$ \\
\hline $\begin{array}{c}\text { EC } \\
(\mu \mathrm{S} / \mathrm{cm})\end{array}$ & 1.0 & -0.1 & 0.1 & 0.0 & 0.4 & 0.9 & 0.8 & 1.0 & 0.5 & 0.4 & 0.8 & 0.8 & -0.2 & -0.2 & -0.3 & 0.2 & -0.3 & -0.2 \\
\hline $\mathrm{pH}$ value & & 1.0 & 0.4 & 0.3 & -0.3 & -0.2 & -0.1 & 0.0 & 0.4 & 0.5 & 0.0 & -0.2 & 0.3 & 0.1 & 0.0 & -0.3 & -0.2 & -0.3 \\
\hline $\mathrm{DO} \mathrm{mg} / \mathrm{L}$ & & & 1.0 & 0.7 & -0.3 & 0.2 & -0.1 & 0.1 & 0.3 & 0.3 & -0.1 & 0.1 & -0.1 & -0.1 & -0.4 & -0.1 & 0.4 & -0.5 \\
\hline Redox mV & & & & 1.0 & -0.4 & -0.1 & 0.0 & -0.2 & 0.1 & 0.5 & -0.3 & 0.2 & -0.1 & -0.4 & -0.7 & -0.6 & 0.5 & -0.4 \\
\hline Temp. ${ }^{\circ} \mathrm{C}$ & & & & & 1.0 & 0.2 & 0.5 & 0.4 & -0.3 & -0.2 & 0.6 & 0.2 & -0.4 & -0.1 & -0.2 & 0.4 & -0.4 & -0.2 \\
\hline $\mathrm{Ca} \mathrm{mg} / \mathrm{L}$ & & & & & & 1.0 & 0.7 & 0.7 & 0.3 & 0.2 & 0.6 & 0.9 & -0.2 & -0.3 & -0.5 & 0.4 & 0.4 & -0.2 \\
\hline $\mathrm{Mg} \mathrm{mg/L}$ & & & & & & & 1.0 & 0.7 & 0.1 & 0.5 & 0.5 & 0.8 & 0.0 & -0.2 & -0.2 & 0.0 & 0.2 & -0.4 \\
\hline $\mathrm{Na} \mathrm{mg/L}$ & & & & & & & & 1.0 & 0.6 & 0.4 & 0.9 & 0.6 & -0.2 & -0.1 & -0.2 & 0.5 & 0.0 & -0.2 \\
\hline $\mathrm{K} \mathrm{mg/L}$ & & & & & & & & & 1.0 & 0.5 & 0.5 & 0.1 & 0.2 & -0.2 & 0.0 & 0.4 & 0.1 & 0.0 \\
\hline $\mathrm{Cl} \mathrm{mg/L}$ & & & & & & & & & & 1.0 & 0.1 & 0.3 & 0.4 & 0.0 & 0.0 & -0.5 & 0.3 & -0.5 \\
\hline $\mathrm{SO}_{4} \mathrm{mg} / \mathrm{L}$ & & & & & & & & & & & 1.0 & 0.3 & -0.4 & 0.0 & -0.1 & 0.7 & -0.2 & -0.1 \\
\hline $\begin{array}{c}\mathrm{HCO}_{3} \\
\mathrm{mg} / \mathrm{L}\end{array}$ & & & & & & & & & & & & 1.0 & -0.1 & -0.3 & -0.4 & 0.1 & 0.5 & -0.3 \\
\hline $\mathrm{NO}_{3} \mathrm{mg} / \mathrm{L}$ & & & & & & & & & & & & & 1.0 & -0.2 & -0.2 & -0.5 & -0.2 & -0.2 \\
\hline $\mathrm{Fe}^{+2} \mathrm{mg} / \mathrm{L}$ & & & & & & & & & & & & & & 1.0 & 0.7 & -0.1 & -0.2 & -0.1 \\
\hline As $\mathrm{mg} / \mathrm{L}$ & & & & & & & & & & & & & & & 1.0 & -0.2 & 0.3 & 0.4 \\
\hline Mo mg/L & & & & & & & & & & & & & & & & 1.0 & -0.1 & 0.0 \\
\hline $\mathrm{Ni} \mathrm{mg/L}$ & & & & & & & & & & & & & & & & & 1.0 & 0.8 \\
\hline $\mathrm{U} \mathrm{mg} / \mathrm{L}$ & & & & & & & & & & & & & & & & & & 1.0 \\
\hline
\end{tabular}

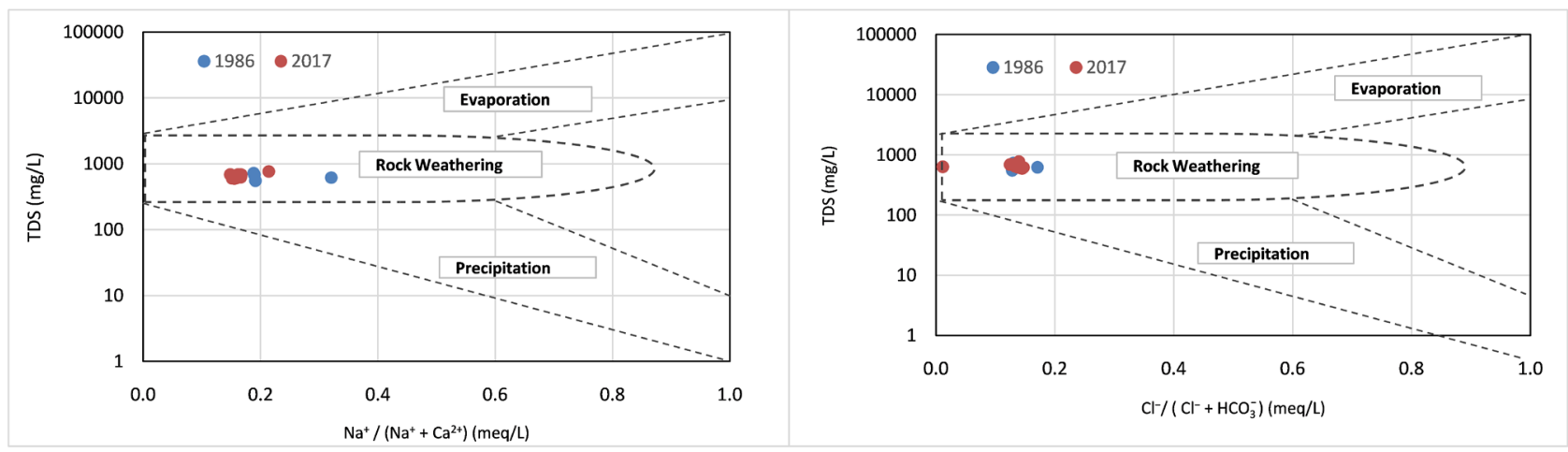

Figure 4. Gibbs diagram showing factors controlling the groundwater chemistry [26].

To further know the functional relationship of the dissolved ions and their contribution to the groundwater the data are plotted in the scatter diagram in Figure 5; Based on the Equations (1) and (2) above the dissolution of calcite and dolomite would produce the $\mathrm{Ca}^{2+} / \mathrm{HCO}_{3}^{-}$and $\left(\mathrm{Ca}^{2+}+\mathrm{Mg}^{2+}\right) / \mathrm{HCO}_{3}^{-}$with a molar ratio of (0.5). In this study; the $\mathrm{Ca}^{2+} / \mathrm{HCO}_{3}^{-}$ratios of most samples are above (1) as a result of the dissolution of calcite, while $\left(\mathrm{Ca}^{2+}+\mathrm{Mg}^{2+}\right) / \mathrm{HCO}_{3}^{-}$ ratios are below (1). 

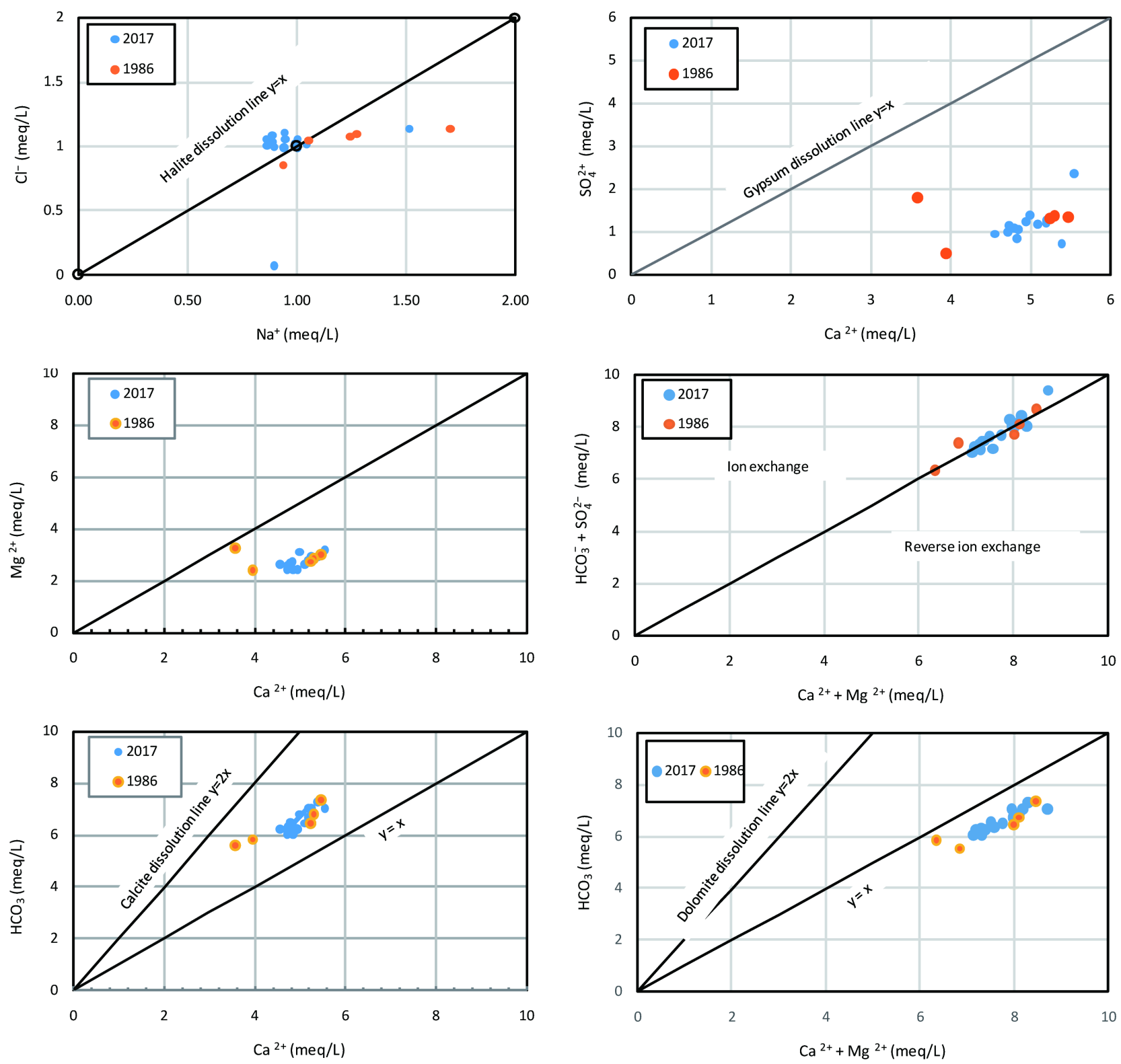

Figure 5. Distributions diagram of ionic ratios in water samples.

Additionally when the $\mathrm{Ca}^{2+} / \mathrm{Mg}^{2+}$ molar ratio below (1) the groundwater is undersaturated with respect to $\mathrm{Mg}^{2+}$ which triggers the dissolution of dolomite, most of the plotted samples had the $\mathrm{Ca}^{2+} / \mathrm{Mg}^{2+}$ molar ratios largely less than (1) which indicate the dissolution of the aquifer matrix dolomites. Moreover, if the $\mathrm{Ca}^{2+} / \mathrm{Mg}^{2+}$ molar ratio greater than (2) can be the result of the dissolution of silicate minerals (silicified limestone and chert).

The relation of $\mathrm{Na}^{+} / \mathrm{Cl}^{-}$molar ratio indicates whether the $\mathrm{Na}^{+}$was derived from the dissolution of halite. The $\mathrm{Na}^{+} / \mathrm{Cl}^{-}$molar ratio of most water samples is less than 1 in the analyzed samples collected during 2017. While the 1986 ratio is equal or more than 1 . This is attributed to the weathering action of silicate minerals. 
The $\mathrm{Ca}^{2+}$ and $\mathrm{SO}_{4}^{2-}$ concentrations of groundwater are controlled by gypsum dissolution and precipitation processes (Equation (3)), the ratio between $\mathrm{Ca}^{2+}$ and $\mathrm{SO}_{4}^{2-}$ showed enriched $\mathrm{Ca}^{2+}$ anddeficient $\mathrm{SO}_{4}^{2-}$ concentration.

$$
\mathrm{CaSO}_{4} \cdot 2 \mathrm{H}_{2} \mathrm{O} \rightleftarrows \mathrm{Ca}^{2+}+\mathrm{SO}_{4}^{2-}+2 \mathrm{H}_{2} \mathrm{O}
$$

The relation between $\left(\mathrm{Ca}^{2+}+\mathrm{Mg}^{2+}\right)$ versus $\left(\mathrm{HCO}_{3}^{-}+\mathrm{SO}_{4}^{2-}\right)$ identifies whether ion exchange or reverse ion exchange is the dominant process based on Equations (4) and (5).

$$
\text { Ion exchange: } 2 \mathrm{Na}^{+} \text {-Clay }+\mathrm{Ca}^{2+} \rightarrow 2 \mathrm{Na}^{+}+\mathrm{Ca}^{2+}-\mathrm{Clay}_{2}
$$

Reverse Ion exchange: $\mathrm{Ca}^{2+}-\mathrm{Clay}_{2}+2 \mathrm{Na}^{+} \rightarrow \mathrm{Ca}^{2+}+2 \mathrm{Na}^{+}$-Clay

The result of the scatter plot showed that most of the samples falling along the equiline of $\left(\mathrm{HCO}_{3}^{-}+\mathrm{SO}_{4}^{2-}\right) /\left(\mathrm{Ca}^{2+}+\mathrm{Mg}^{2+}\right)$ ratio. Can assume that the $\mathrm{Ca}^{2+}$ and $\mathrm{Mg}^{2+}$ are in equilibrium and signify the result of carbonate weathering.

\subsection{Minerals Saturations}

The equilibrium state of the water with respect to a mineral phase can be determined by calculating a saturation index (SI) which gives insight of minerals reactivity and can reflect the thermodynamic process of natural water systems, SI values (Equation (6)) of water samples were calculated using Phreeqc Interactive Software.

$$
\mathrm{SI}=\log (\mathrm{IAP}) / \mathrm{K}
$$

The calculated results for groundwater samples are shown in (Table 5) Most of the water samples yielded SI calculated results as follows: calcite is supersaturated, dolomite is approximately saturated to supersaturated; which released from the dissolution of carbonate rock (A7/B2) aquifer of Wadi Al Arab. All of the groundwater samples were under-saturated to gypsum and Halite because the major lithological units of the Wadi Al Arab area are insufficient in respect to these minerals.

\subsection{Critical Parameter}

In order to consider the groundwater safe and portable, its contents must concurrently meet the set standards. Some of these constituents occur in significant amounts with the main ions and others are present as trace elements. The water in the study area shows enrichment of trace elements largely with Mo followed by less concentration amounts of $\mathrm{Ni}$, As, and $\mathrm{U}$. Those categorized as critical parameter relevant from a health prospective based on the JSMO standard (2015) and WHO (2017) and can be harmful to the human health.

The increased concentration of Molybdenum in Wadi Al Arab wells starting from 2008 exceeding the threshold in standards with time (Figure 6), which clearly present the spatial heterogeneity of Mo Groundwater concentration in Wadi Al Arab Aquifer.

The incremental increase of molybdenum concentration in the groundwater 
Table 5. Saturation index value for Calcite, Dolomite, Gypsum, and Halite.

\begin{tabular}{|c|c|c|c|c|c|}
\hline Well Name & Sample Year & SI of Calcite & SI of Dolomite & SI of Gypsum & SI ofHalite \\
\hline WA 1 & 1986 & 0.63 & 0.86 & -1.68 & -7.56 \\
\hline WA 2 & 1986 & 0.91 & 1.42 & -1.97 & -7.77 \\
\hline WA 3 & 1986 & 1.02 & 1.65 & -1.73 & -7.67 \\
\hline WA 4 & 1986 & 1.07 & 1.99 & -1.88 & -7.38 \\
\hline WA 5 & 1986 & 0.77 & 0.17 & -1.90 & -7.83 \\
\hline WA 1 & 2017 & 0.08152 & -0.08 & -1.73 & -7.65 \\
\hline WA 2 & 2017 & -0.1132 & -0.01 & -1.83 & -7.73 \\
\hline WA 3 & 2017 & $-786 \times 10^{-6}$ & -0.16 & -1.75 & -7.67 \\
\hline WA $3 \mathrm{~A}$ & 2017 & 0.12 & 0.01 & -1.76 & -7.67 \\
\hline WA 4 & 2017 & 0.4018 & 0.61 & -1.49 & -7.45 \\
\hline WA 5 & 2017 & 0.7179 & 1.16 & -1.94 & -7.64 \\
\hline WA 9 & 2017 & 0.1603 & 0.15 & -2.08 & -7.68 \\
\hline WA 10 & 2017 & 0.1253 & 0.1 & -1.98 & -7.65 \\
\hline WA $11 \mathrm{~A}$ & 2017 & 0.1381 & 0.13 & -1.96 & -7.71 \\
\hline WA 12 & 2017 & -0.03169 & -0.17 & -1.78 & -7.71 \\
\hline WA $13 \mathrm{~A}$ & 2017 & 0.02588 & -0.09 & -1.86 & -7.72 \\
\hline WA 14 & 2017 & 0.2891 & 0.39 & -1.82 & -7.67 \\
\hline WA 15 & 2017 & 0.4075 & 0.54 & -1.77 & -7.71 \\
\hline WA 16 & 2017 & 0.1609 & 0.12 & -1.84 & -7.73 \\
\hline WA 17 & 2017 & 0.2071 & 0.29 & -1.74 & -7.67 \\
\hline WA 18 & 2017 & 0.146 & 0.14 & -1.78 & -7.67 \\
\hline
\end{tabular}

with maximum concentration of $1.62 \mathrm{mg} / \mathrm{L}$ in well 11a. A correlation of the heavy metal Mo, As, $\mathrm{Ni}$, and $\mathrm{U}$ are conducted. In the scattered plot of the Mo with other critical heavy metals (Figure 7), it clearly shows a different trend line. Such concentrations suggest that the Mo was originated and contributed to the groundwater from two different sources which could be the oil shale and the phosphate host rocks.

The wells are divided into two groups based on the correlation behavior of the heavy metal;

- Group 1: includes well name WA11a, WA15, WA5, WA14 which are located in the southern part of the catchment area, at the unconfined aquifer (Figure 7) and have the same behavior.

- Group 2: includes well name WA02, WA3, WA3a, WA13a, which are located in the northern part of the catchment area, at the confined aquifer (Figure 7) and have the same behavior too. 

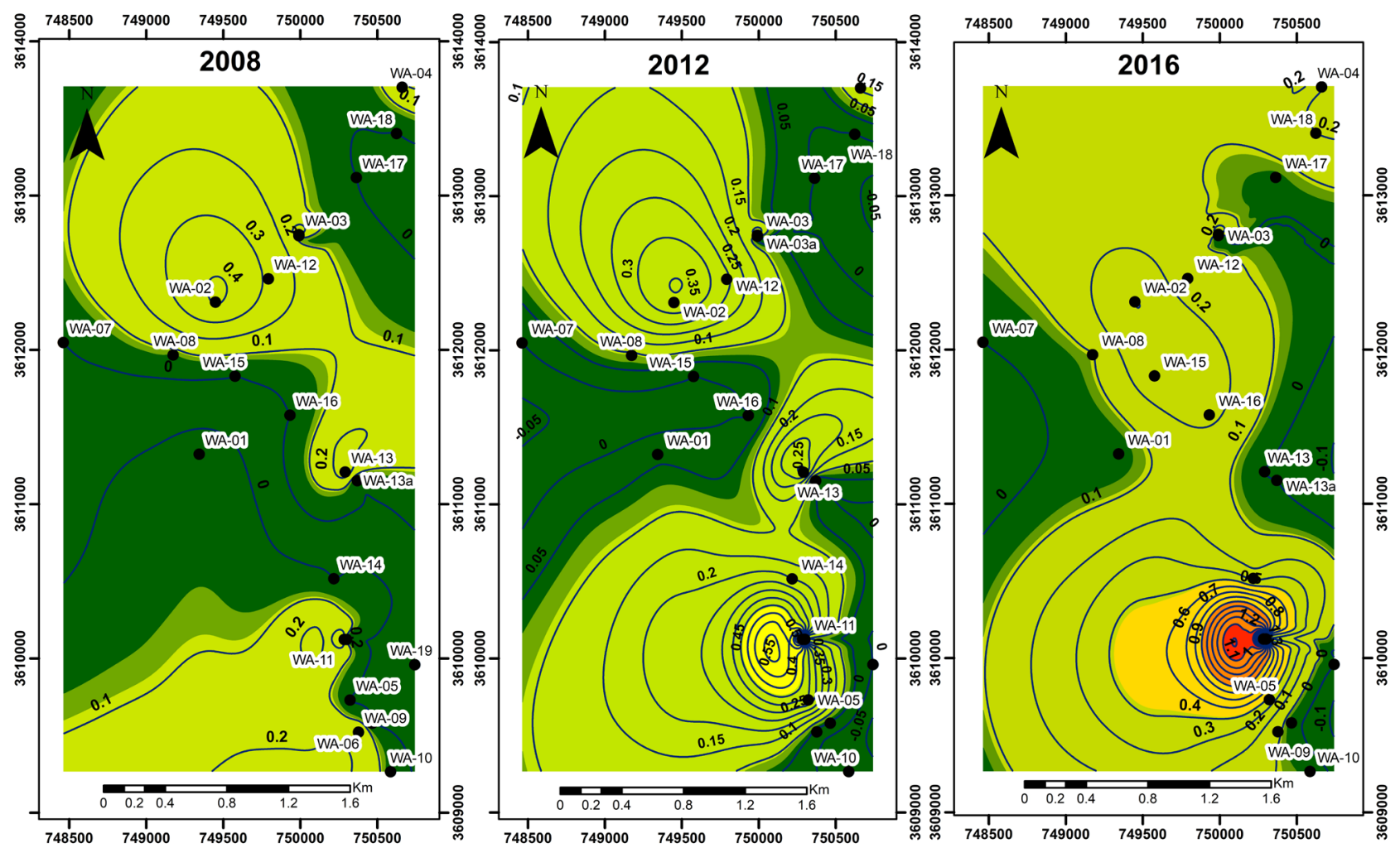

Molybdenum Concentration at Wadi Al Arab Wells (mg/L)

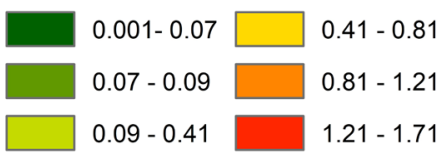

Figure 6. Spatial Variability maps of Mo concentration.

\subsection{Redox Condition of Groundwater in the Carbonate Aquifer}

Reduction/oxidation (Redox) processes affect the chemical quality of the groundwater in the aquifer system [27]. The redox conditions of groundwater reflect those of their reservoir rocks, even though chemical equilibrium is not usually reached between all minerals present and the groundwater.

The effects of $\mathrm{pH}$ and redox potential on Mo mobility in water are reviewed using the paurbaix diagram (Figure 8). As the Mo is highly soluble in water, it is usually present in the form of an oxyanion, and relatively weak in terms of sorption onto geological media with a low organic content [28].

The paurbaix diagram present (electro-potential/ $\mathrm{pH}(\mathrm{pE} / \mathrm{pH})$ diagram) for Mo. Oxidizing and reducing conditions are described by the $y$-axis of the diagram (higher positive electrode potential $=$ more oxidizing environment). The acidic and alkaline conditions of the environment are described by $\mathrm{x}$-axis $(\mathrm{pH}$ conditions).

The common redox states of Mo in the environment ranges from +4 to +6 (Mo (IV) to Mo (VI)). Under the oxic or nitrate reducing condition the most oxidizing Mo species molybdate $\left(\mathrm{MoO}_{4}^{2-}\right)$ and hydrogen molybdate $\left(\mathrm{HMoO}_{4}^{-}\right)$ 


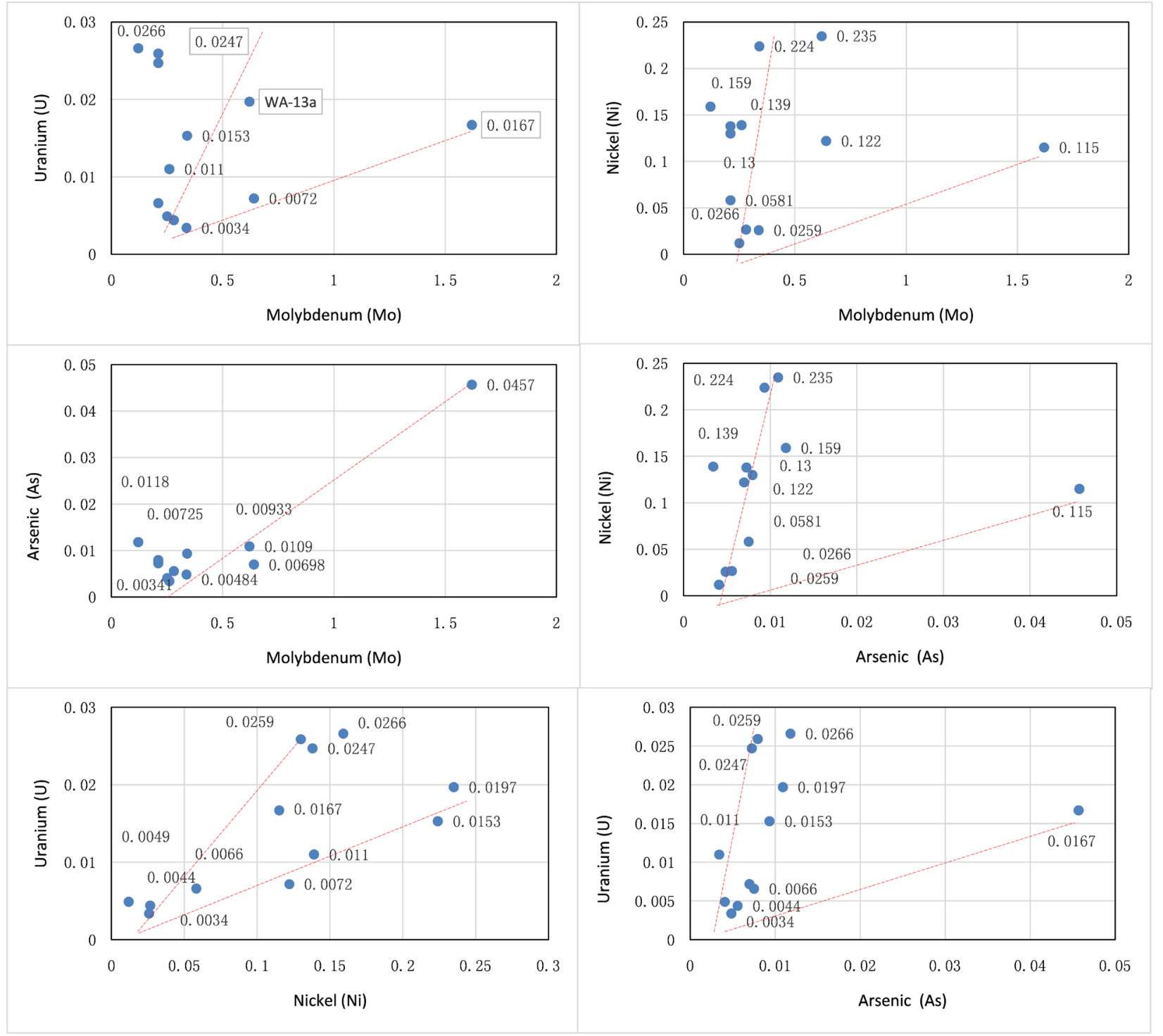

Figure 7. The correlation behavior of the heavy metal.

are expected to be the dominant species under neutral $\mathrm{pH}$ condition $(\mathrm{pH}=6$ 8). Both $\mathrm{MoO}_{4}^{2-}$ and $\mathrm{HMoO}_{4}^{-}$are very mobile.

Under iron reducing conditions, $\mathrm{Mo}(\mathrm{VI})$ species can be reduced to $\mathrm{Mo}(\mathrm{V})$ species $\left(\mathrm{MoO}_{2}^{+}\right)$. Under anaerobic highly sulfidic conditions, Mo can be further reduced to a solid form as Mo disulfide (or Molybdenite, $\mathrm{MoS}_{2}$ ), which is considered immobile in the aquifer [29].

The Mo species in the twelve sampled wells are confined to the field of $\mathrm{MoO}_{4}^{(2-)}$; Anoxic/non sulfidic condition (Fe reduction) which is located in the unconfined part of the aquifer, and $\mathrm{MoS}_{2}^{(\mathrm{s})}$ which is Sulfidic condition (low and high) in the confined aquifer.

The $\mathrm{MoS}_{2}$ is not soluble in water; oxidation of this mineral will result in the production of molybdate oxyanion, which is very mobile in water. The stoichiometry of the reaction can be expressed as in Equation (7). 


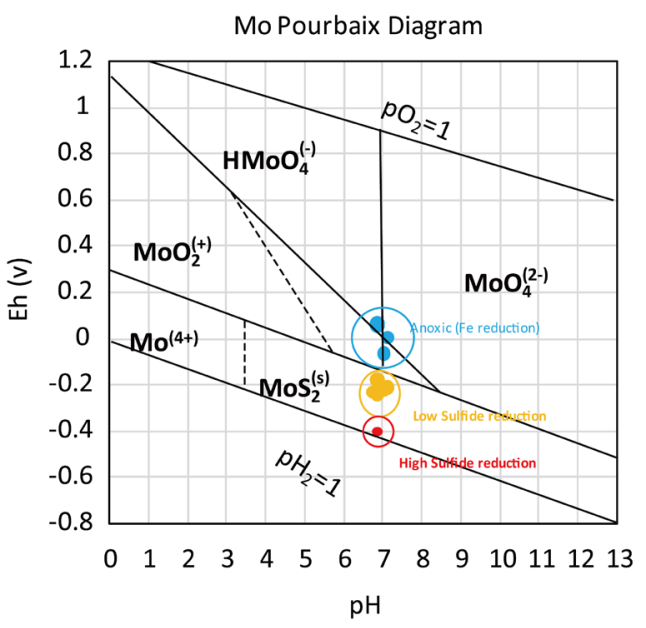

Figure 8. Paurbaix diagram for molybdenum adapted from Wang (2007).

$$
2 \mathrm{MoS}_{2}+9 \mathrm{O}_{2}+6 \mathrm{H}_{2} \mathrm{O} \rightarrow 2 \mathrm{MoO}_{4}^{2-}+12 \mathrm{H}^{+}
$$

Similarly, oxidation of other Mo-Bearing sulfides, such us Pyrite, may also result in production of molybdate. Iron or Sulfide oxidizing bacteria have the potential to facilitate metal leaching but in anoxic or anaerobic condition bioleaching reaction is expected to be very slow [30] [31].

\section{Conclusions}

The highest value of molybdenum measured in Wadi Al Arab is confined to the field of $\mathrm{MoO}_{4}^{(2-)}$ : anoxic/non-sulfidic condition (Fe reduction), which is located in the unconfined part of the aquifer, and $\mathrm{MoS}_{2}^{(\mathrm{s})}$ which is Sulfidic condition (low and high) in the confined aquifer.

The result of the correlation of heavy metal Mo, As, Ni, and $U$ shows two different trend lines, suggesting that Mo originated and contributed to groundwater from two different sources are mainly the oil shale and the phosphate deposits.

The various concentrations and the different behaviors of molybdenum in the wells located in the northern and southern well fields are still questionable. This could be related to the hydrogeochemical evolution along different separate groundwater flow paths. This evolution represents the chemical weathering and oxidation-reduction reactions, which reflect the degree of Mo mobilizations, as well as mineral co-precipitation/re-adsorption reactions that dictate the degree of Mo immobilization that needs to demonstrate further explanations.

More tests should be conducted to set and to evaluate the complex of Mo behaviors regarding the factors that may affect the transport of Mo under varying redox, $\mathrm{pH}$, and geological media condition, and to assess the fractionation of Mo in the two sources of aquifer matrix.

\section{Acknowledgements}

The authors gratefully acknowledged the financial support provided by the Uni- 
versity of Jordan, Deanship of Scientific Research at for the presented work in this paper.

\section{Conflicts of Interest}

The authors declare no conflicts of interest regarding the publication of this paper.

\section{References}

[1] Pichler, T. and Mozaffari, A. (2015) Occurrence, Distribution and Mobility of Geogenic Molybdenum and Arsenic in A Limestone Aquifer Matrix. Applied Geochemistry, 63, 623-633. https://doi.org/10.1016/j.apgeochem.2015.08.006

[2] Pichler, T., Renshaw, C.E. and Sültenfuß, J. (2016) Geogenic As and Mo Groundwater Contamination Caused by an Abundance of Domestic Supply Wells. Applied Geochemistry, 77, 68-79. https://doi.org/10.1016/j.apgeochem.2016.03.002

[3] Ferguson, J.F. and Gavis, J. (1972) A Review of the Arsenic Cycle in Nature Waters. Water Research, 6, 1259-1274. https://doi.org/10.1016/0043-1354(72)90052-8

[4] Amini, M., Abbaspour, K.C., Berg, M., Winkel, L., Hug, S.J., Hoehn, E., Yang, H. and Johnson, C.A. (2008) Statistical Modeling of Global Geogenic Arsenic Contamination in Groundwater. Environmental Science \& Technology, 42, 3669-3675. https://doi.org/10.1021/es702859e

[5] Al Kuisi, M., Al-Hwaiti, M. and Mashal, K. (2015) Spatial Distribution Patterns of Molybdenum (Mo) Concentrations in Potable Groundwater in Northern Jordan. Environmental Monitoring and Assessment, 187, 148. https://doi.org/10.1007/s10661-015-4264-5

[6] El-Naqa, A., Ibrahim, K. and Abu Alrous, M. (2018) Hydrogeochemical Investigation of the Origin of Molybdenum (Mo) in Groundwater Resources in Wadi Al Arab Area, Northern Jordan. Acque Sotterranee-Italian Journal of Groundwater, 7, 19-30. https://doi.org/10.7343/as-2018-341

[7] Rimawi, O. (1985) Hydrogeochemistry and Isotope Hydrology of the Ground and Surface Water in North Jordan (North-Northeast of Mafraq, Dhuleil-Hallabat, Azraq-Basin). PhD Thesis, TU Muenchen, Germany.

[8] World Health Organization (WHO) (2011) Guidelines for Drinking Water Quality. 4th Edition, Geneva.

http://www.who.int/water_sanitation_health/publications/2011/dwq_guidelines/en/

[9] Jordanian Institute of Standards and Metrology (JISM) (2008) Drinking Water Standards. No. 286/2008, Amman.

[10] Abed, A.M. and Amireh, B. (1983) Petrography and Geochemistry of Some Jordanian Oilshale from North Jordan. Journal of Petroleum Geology, 5, 261-274. https://doi.org/10.1111/j.1747-5457.1983.tb00571.x

[11] Abed, A.M., Sadaqah, R. and Al Kuisi, M. (2008) Uranium and Potentially Toxic Metals During the Mining, Beneficiation and Processing of Phosphorite and Their Effect on Groundwater in Jordan. Mine Water Environment, 27, 171-182. https://doi.org/10.1007/s10230-008-0039-3

[12] Smedley, P.L. and Kinniburgh, D.G. (2017) Molybdenum in Natural Waters: A Review of Occurrence, Distributions and Controls. Applied Geochemistry, 84, 387-432. https://doi.org/10.1016/j.apgeochem.2017.05.008

[13] Margana, A. (2006) Hydrogeological Proposal for the Delineation of a Groundwater 
Protection Area for the Wadi Al Arab Well Field. Technical Cooperation Project WI-BGR, Ministry of Water and Irrigation, Amman.

[14] Margane, A., Hobler, M., Almomani, M. and Subah, A. (2002) Contributions to the Groundwater Resources of Northern and Central Jordan. Geologisches Jahrbuch, C. Hannover, No. 68, 52 p.

[15] Margane, A. (1995) Groundwater Resources of Northern Jordan, Vol.2, Part 2: Monitoring of Groundwater Levels in Northern Jordan. Technical Cooperation Project "Advisory Services to the Water Authority of Jordan. BGR \& WAJ, BGR Archive No. 118701, Amman.

[16] Margane, A., Al-Qadi, M. and Al-Kurdi, O. (2015) Updating the Groundwater Contour Map of the A7/B2 Aquifer in North Jordan. Technical Cooperation Project 'Syrian Refugee Response', Technical Report No. 1, BGR \& MWI, Amman, 129 p.

[17] El-Naser, H. (1991) Groundwater Resources of the Deep Aquifer System in Northwest Jordan. PhD Thesis, University of Wurzburg, Wurzburg, Germany.

[18] Salameh, E. and Rimawi, O. (1984) Isotope Analyses and Hydrochemistry of the Thermal Springs along the Eastern Side of the Jordan Dead Sea-Wadi Araba Rift Valley. Journal of Hydrology, 73, 129-145. https://doi.org/10.1016/0022-1694(84)90036-2

[19] Rimawi, O., El-Naqa, A. and Salameh, E. (1984) Hydrochemichal Characteristics of Groundwater Resources in the Northesastren Part of the Jordan. Volume 19B, University of Jordan, Dirasat.

[20] Powell, J.H. (1989) Stratigraphy and Sedimentation of the Phanerozoic Rocks in Central and Southern Jordan. Bulletin 11, Natural Resources Authority, Amman.

[21] Basem, K.M. (2000) The Geology of Irbid and Ash Shuna Ash Shamaliyya (Waqqas) Map Sheets No. 3154-II and 3154-III. Geology Directorate, Natural Resources Authority, Amman, Jordan, Bulletin 46, 9 p.

[22] Parker, D.H. (1970) The Hydrogeology of the Mesozoic-Cainozoic Aquifers of the Western Highlands and Plateau of East Jordan (4 Volumes). UNDP/FAO 212. Unpublished Technical Report, No. 2, 424 p.

[23] Abed, A. (2000) Geology of Jordan (In Arabic). Geological Association of Jordan, Amman.

[24] Salameh, E. and Udluft, P. (1985) The Hydrodynamic Pattern of the Central Part of Jordan. Geologisches Jahrbuch, 38, 39-35.

[25] Piper, A.M. (1944) A Graphic Procedure in Geochemical Interpretation of Water Analysis. Transactions of the American Geophysical Union, 25, 914-928. https://doi.org/10.1029/TR025i006p00914

[26] Gibbs, R. (1971) Mechanism Controlling World River Water Chemistry: Evaporation-Crystallization Process. Science, 172, 871-872. https://doi.org/10.1126/science.172.3985.870

[27] Smedley, P.L., Cooper, D.M., Ander, E.L., Milne, C.J. and Lapworth, D.J. (2014) Occurrence of Molybdenum in British Surface Water and Groundwater: Distributions, Controls and Implications for Water Supply. Applied Geochemistry, 40, 144-154. https://doi.org/10.1016/j.apgeochem.2013.03.014

[28] Vlek, P.L.G. and Lindsay, W.L. (1977) Thermodynamic Stability and Solubility of Molybdenum Minerals in Soils. Soil Science Society of America Journal, 41, 42-46. https://doi.org/10.2136/sssaj1977.03615995004100010016x

[29] Wang, D. (2007) Biogeochemistry of Redox-Sensitive Elements in Natural Waters: Chemical Speciation of Molybdenum and Vanadium. Doctoral dissertation, Stony 
Brook University, Stony Brook, NY.

[30] Helz, G.R., Bura-Nakić, E., Mikac, N. and Ciglenečki, I. (2011) New Model for Molybdenum Behavior in Euxinic Waters. Chemical Geology, 284, 323-332.

https://doi.org/10.1016/j.chemgeo.2011.03.012

[31] Erickson, B. and Helz, G. (2000) Molybdenum (VI) Speciation in Sulfidic Waters: Stability and Lability of Thiomolybdates. Geochimica et Cosmochimica Acta, 64, 1149-1158. https://doi.org/10.1016/S0016-7037(99)00423-8 